\title{
The Effectiveness Of Communication Of Subordinates To Superiors
} (Optimizing Gadget)

\author{
Widdy Endrayanto, Toho Cholik Mutohir, Soedjarwo, Mudjito \\ Universitas Negeri Surabaya \\ Surabaya, Indonesia \\ widdyendrayanto77@gmail.com
}

\begin{abstract}
Communication as a human relational "path" through which principal leadership influenced teacher professional learning. This study was conducted at Petra Christian Vocational High School. The purpose of this study is so that subordinates can communicate effectively with leaders, and that subordinates optimize gadgets in communicating. The method uses the descriptive method with case study research that uses qualitative analysisThe study participants were 40 subordinates of Petra Christian Vocational High School, which were determined purposefully. The data was collected using indepth interviewing, participant observation, and study of documents. The result of this study shows the subordinates have been able to understand effective communication materialsThe subordinates are motivated to implement the effective communications to superiors. The boss also experienced an increase in behavior but was not optimal. Communication requires emotional intelligence. Even though there are gadgets, the use of conventional letters and oral communication is still effective
\end{abstract}

Keywords - communication; emotional intelligence; gadgets; subordinates; superiors.

\section{INTRODUCTION}

Communication is the delivery of information from one party to another [1]. Communication can use conventional tools as well as modern media such as gadgets. I chose a gadget because people are familiar with it[2]. Communication barriers can occur in the relationship between communicator and communicate.

The boss is the leader. In this study were principals and leaders of the human resources department. Subordinates are people who are under orders. In this study are teachers, administration, cleaning service, security. Communication barriers can occur between subordinates and superiors[3]. No result found for Initially the attitude and speech of the principal were not polite to some of his subordinates.

Subordinates feel uncomfortable about the attitude of the principal. Subordinates conduct focus group discussions using gadgets[4]. Subordinates want to give advice to the principal. Subordinates do not dare to express their opinions even though they use gadgets. The research question is how can subordinates be able to communicate effectively to advise the leader? And how to optimize gadgets in communicating verbally and in writing?

The purpose of this study is so that subordinates can communicate effectively with leaders, and that subordinates optimize gadgets in communicating. Carried out are how subordinates get motivation and practice effective communication and subordinates can be better prepared to express their opinions. Obstacles experienced are principals still being closed to suggestions from subordinates[5].

Subordinates tried to find other communication channels. Subordinates carry out Focus Group Discussions and optimize gadgets[6]. Subordinates inform the problem to the head of the institution and the commission in writing. Subordinates communicate effectively with the leadership of the Human Resources Department.

The results of the readiness of the subordinates to communicate are the leaders of the Human Resources Department willing to be subordinate mediators and principals. No result found for the object of this study includes: a) Aspects of context effective communication improvement programs. b) Input aspects how to communicate effectively, which superiors. c) Process aspects media and methods used by training. d) Outcome aspects subordinate attitudes and skills after communication training effective.

\section{METHOD}

This study was conducted at Petra Christian Vocational High School. It is located in Surabaya, East Java, Indonesia. The Study took place in this context because it is a real example of, an institution where people want to learn effective communication with their leader. Want more people to learn effective communication through the gadget.

The participants of the study were 40 people from Petra Christian Vocational High School. They are chosen because they want to work conducive, comfortably, and passionately. 
The number of the participants was considered sufficient to represent the whole employee because it was more half of the total number of the employee. Data analysis using Miles and Huberman. The data were needed to be was collected with in-depth interviewing, participant observation, and study of documents, administered in July 2017.

The in-depth interviewing, participant observation, and study of documents consist of five problems as follows: 1) Why do you prefer learning communication? 2) What do you want to have after learning effective communication in this institution? 3) What do you want your effective communication like after learning it in the institution? 4) What do you want the leader to think about you as an effective communicator? 5) What do you feel while learning effective communication?

I chose the in-depth interviewing, participant observation, and study of documents because I did not want to limit the participants' thoughts and responses to the problem given. Before conducting the in-depth interviewing, participant observation, and study of documents, I did a piloting first in order to test whether the directions and the question items of the interview and observation were clear enough.

The forty people were regarded as the representatives of the real participants later. Data analysis using Miles and Huberman; a) Data collection, b) Data reduction, c) Presentation of data, d) Drawing conclusions.

The in-depth interviewing, participant observation, and study of documents were designed to reveal the participants' imagined communities of the following categories: 1) Communication mastery (related to what the peoples want their communication will be; question 2 and 3), 2) Occupation (related to what the peoples want to be after graduating; question 2), 3) The expectation for the future (related to what the peoples want to do with their communication; the question 2 and 4)[7].

In grouping the data, I found that the data could still be grouped into smaller categories as: "comprehension", "occupation", "for themselves", and "for the others", for "expectation for the future", "self-qualify". "Attitude", and "Leader Recognition".

The data was then counted quantitatively to see the total responses of the participant for each category. The qualitative data of the participants were analyzed qualitatively. The analysis was described in a descriptive way. I named the participants with pseudonyms, represented by an alphabet.

\section{RESULT AND DISCUSSION}

They wrote that communication would be useful because learning, communication In addition to communication mastery and occupations, the participants of this study also had their imagined communities concerning their future expectations as effective communication learners[8].
Moreover, a participant explained that effective communication was the bridge to communication with all people. This case shows that the participants' imagined communities were not only about their own future and importance, but the participants also imagined the future of the people in their surroundings after they were able to use effective communication.

The imagined communities of the participants were not only in the form of how they wanted their own future would be and what they can do with effective communication, but the participants also cared about how the leader would see them as effective communicators. Related to attitude, participants' imagined communities were about how the participants wanted the society to see their attitude as effective communicators later on.

It is no doubt that the participants wanted the society to see them to have a positive position as an effective communicator in the social life. Subordinates have been motivated to learn effective communication. Subordinates managed to convey suggestions to the principal and the head of the Human Resources Department verbally in the mediation process. The Human Resources Department can accept and understand the subordinates' suggestions [9].

1. The proposition that subordinates have been able to understand communication materials.

2. Participants are motivated to implement the effectiveness of subordinate communications to superiors.

3. The role of the Principal is very strategic to improve effective communication in schools.

4. The Human Resources Leader performs the role of mediation as well.

Researchers found several things: 1) Social media is very effective when subordinates communicate with Human Resources leaders[10]. 2) Fellow subordinates to coordinate with social media. 3) Implementation of the increased effectiveness of communication is very beneficial for subordinates and educational units. 4) Research activities can be programmed again for educational units. 5) The need for sound systems, good infrastructure. 6) Active participants are rewarded. 7) Participants who failed to help solve the problem. 8) Evaluation results to decide on future activities. 9) Human resource management support is necessary[11].

This study has revealed the imagined communities of an employee of Petra Christian Vocational High School in learning effective communication more profoundly which have been considered as an important factor for participants' learning trajectories, motivation, investment, and resistance in learning the effective communication.

The communication from subordinates to superiors is very effective in giving constructive suggestions[12]. But that opinion did not apply in my research. Each participant had their own imaginations for their future. Related to effective communication mastery, the participants had set 
their desired comprehension, pronunciation, fluency and accuracy. The discussion has shown that the most consideration of the participants was about their pronunciation and intonations. The participants also had a different point of views for their imagined communities about future occupations. Some of them mentioned concrete occupations such as effective communication, humble person, role model, negotiator.

While the data, I also a good conclusion that the participants' imaginations revealed above had become their reason in deciding to learn effective communication more profoundly.

The result of this present study is also a consideration for the human resources development department leader in designing their development activities, preparing, communicating materials, and doing exercises which can help the participants achieving their imaginations[13]. This research, however, cannot be generalized to all contexts because the imagined communities of effective communication, the learner may be different from one context to the others, or even for different participants. The results of this study may be used at a glance for other similar researches on the imagined communities in effective communication learning.

\section{CONCLUSION}

It turns out that subordinate communication to principals is not always effective. There is a basis for communication because the principal is still closed from a subordinate input. Communication requires emotional intelligence[14].

In my opinion, even though there are gadgets, the use of conventional letters and oral delivery is still effective. It is also interesting to investigate the imagined communities of human resources development department leaders which might relate to how they deliver the materials and design the classroom activities. I suggest for further research to ask about how principals get effective communication training effective.

\section{REFERENCES}

[1] I. Halawah, "The relationship between effective communication of high school principal and school climate.," Education, vol. 126, no. 2, 2005.

[2] E. Hassan, V. Raan, V. Raan, and T. Linkages, "Simultaneous Mapping of Interactions between Scientific and Technological Knowledge Bases: The Case of Space Communications Published Online: 30 Jan 2003," J. Am. Soc. Inf. Sci. Technol., vol. 54, no. 5, pp. 462-468, 2003.

[3] S. Boerner, S. A. Eisenbeiss, and D. Griesser, "Follower Behavior and Organizational Performance: The Impact of Transformational Leaders," J. Leadersh. Organ. Stud., vol. 13, no. 3, pp. 15-26, 2007.

[4] J. P. Near, T. M. Dworkin, and M. P. Miceli, "Explaining the Whistle-Blowing Process: Suggestions from Power Theory and Justice Theory," Organ. Sci., vol. 4, no. 3, pp. 393-411, 1993.

[5] K. Thompson, "Risks and Rewards of Blowing the Whistle.," Phi Kappa Phi Forum, vol. 92, no. 3, p. 24, 2012.

[6] B.-K. (Brian) Joo, B. Yang, and G. N. McLean, "Employee creativity: the effects of perceived learning culture, leader-member exchange quality, job autonomy, and proactivity," Hum. Resour. Dev. Int., vol. 17, no. 3, pp. 297-317, 2014.

[7] S. Norris, S. Sitton, and M. Baker, "Mentorship Through the Lens of Servant Leadership: The Importance of Accountability and Empowerment 1," NACTA J., vol. 61, no. 1, p. 21, 2017.

[8] J. CHAFRA and H. ERKUTLU, "Authentic Leadership and Organizational Job Embeddedness in Higher Education," Hacettepe Univ. J. Educ., vol. 32, no. 2, pp. 1-1, 2016.

[9] H. Zhao, M. Kessel, and J. Kratzer, "Supervisor-subordinate relationship, differentiation, and employee creativity: A selfcategorization perspective," J. Creat. Behav., vol. 48, no. 3, pp. 165184, 2014.

[10] S. Gillard, D. Bailey, and E. Nolan, "Ten Reasons for IT Educators to be Early Adopters of IT Innovations," J. Inf. Technol. Educ. Res., vol. 7, no. 1, pp. 21-33, 2008.

[11] F. O. Walumbwa, S. J. Peterson, B. J. Avolio, and C. A. Hartnell, “an Investigation of the Relationships Among Leader and Follower Psychological Capital, Service Climate, and Job Performance," Pers. Psychol., vol. 63, no. 4, pp. 937-963, 2010.

[12] B. Erdogan, T. N. Bauer, and J. Walter, "Deeds that Help and Words that Hurt: Helping and Gossip as Moderators of the Relationship Between Leader-Member Exchange and Advice Network Centrality," Pers. Psychol., vol. 68, no. 1, pp. 185-214, 2015.

[13] R. Riegelman and N. A. Persily, "Health information systems and health communications: Narrowband and broadband technologies as core public health competencies," Am. J. Public Health, vol. 91, no. 8, pp. 1179-1183, 2001.

[14] R. Vecchio, J. Justin, and C. Pearce, "The influence of leader humor on relationships between leader behavior and follower outcomes," $J$. Manag. Issues, vol. XXI, no. 2, pp. 171-194, 2009. 